\title{
PENGARUH IKLAN, KEMUDAHAN PENGGUNAAN, RESIKO DAN CITRA PERUSAHAAN TERHADAP MINAT NASABAH INTERNET BANKING BRI PADA NASABAH BRI UNIT MALABAR TANGERANG
}

\author{
Mahnun Mas'adi ${ }^{1)}$ \\ 1) dosen universitas pamulang, email : dosen01017@unpam.ac.id
}

\section{ARTICLES INFORMATION \\ JURNAL ILMIAH MANAJEMEN FORKAMMA}

\author{
Vol.2, No.1, November 2018 \\ Halaman : 1-16 \\ (c) LPPM \& FORKAMMA
}

Prodi Magister Manajemen UNVERSITAS PAMULANG

ISSN (online) : 2599-171X ISSN (print) : :2598-9545

\section{Keyword : \\ Incentives, motivation,employee performance}

JEL. classification :

C33, G20, G23, N65

\section{Contact Author : \\ PRODI \\ MAGISTER MANAJEMEN \& FORKAMMA UNPAM \\ JL.Surya Kencana No.1 Pamulang \\ Tangerang Selatan - Banten \\ Telp. (021) 7412566, Fax (021) 7412491 Email : \\ jurnalforkamma.unpam@gmail.com}

\section{ABSTRACT}

Tujuan Penelitian ini adalah untuk menganalisis faktorfaktor yang mempengaruhi minat nasabah dalam menggunakan internet banking BRI. Permasalahan penelitian ini adalah masih rendahnya nasabah PT BRI Persero yang melakukan aktivitas perbankan di website resmi BRI. Dalam penelitian ini diajukan model penelitian untuk menganalisis minat nasabah terhadap layanan Internet Banking BRI dengan menguji faktor-faktor yang mempengaruhinya yaitu iklan, kemudahan penggunaan, resiko dan citra perusahaan. Penelitian ini menggunakan sampel 54 orang nasabah BRI Unit Malabar yang sudah pernah menggunakan Internet Banking BRI. Alat analisis data yang digunakan adalah regresi sederhana pada program SPSS versi 18. Hasil analisa data menunjukkan bahwa model penelitian mempunyai kesesuaian yang baik, dan semua hipotesis penelitian dapat dibuktikan. Kesimpulan yang diambil adalah variabel iklan dan variabel resiko secara siginifikan berpengaruh terhadap minat nasabah untuk menggunakan Internet Banking BRI. Namun variabel kemudahan penggunaan dan variabel citra perusahaan tidak memiliki pengaruh yang signifikan terhadap minat menggunakan Internet Banking BRI

The purpose of this studyt to analyzes the factors that affect the interests of customers using internet banking in BRI. This research problem is the low PT BRI Persero customers who do banking activities on the official website of BRI. In this study the proposed research model to analyze the interests of customers of Internet Banking services BRI by examining the factors that influence the advertising, ease of use, risk and corporate image This study used a sample of 54 people Malabar Unit BRI customers who have been using the Internet Banking BRI. Data analysis tool used is a simple regression in SPSS version18. Results of analysis of research data shows that the model has good compatibility, and all the research hypothesis can be proved. The conclusion drawn is advertising and the risk of a significant effect on the interests of customers to use Internet Banking BRI. But the ease of use and image of the company has no significant effect on the interest in using Internet Banking BRI. 


\section{A. Pendahuluan}

Perkembangan teknologi terutama teknologi informasi mengakibatkan perubahan yang sangat besar dalam segala bidang kehidupan masyarakat. Kemajuan teknologi informasi ( $\mathrm{TI})$ yang sangat pesat terutama komputer sebagai motor penggeraknya telah merubah segalanya (Handayani, 2000). Perkembangan TI yang sangat pesat dewasa ini juga memberikan banyak kemudahan pada berbagai aspek kegiatan bisnis (Indriantoro, 2000).

Kemajuan teknologi yang semakin canggih sekarang ini, diyakini berkontribusi besar pada pertumbuhan yang signifikan pada sektor jasa terutama jasa perbankan. Teknologi informasi (TI) berperan signifikan dalam menunjang daya saing setiap perusahaan, misalnya dalam hal penciptaan atau penyampaian jasa baru, peningkatan keterlibatan pelanggan dalam operasional, pembentukan departemen layanan pelanggan tersentralisasi, dan pengembangan database marketing yang akurat. Salah satu bentuk penggunaan $\mathrm{TI}$ adalah internet banking.

Kehadiran internet banking ini telah membawa perubahan yang mendasar pada jenis layanan perbankan, dari yang awalnya banking delivery channels ke arah selfservice channels yaitu internet banking.. Selama beberapa tahun terakhir ini, bank komersial telah memperkenalkan sistem perbankan berbasis internet untuk meningkatkan operasional dan mengurangi biaya. Internet banking merupakan salah satu bentuk produk jasa yang mulai banyak ditawakan oleh bank-bank komersial di Indonesia.

BRI Unit Malabar salah satu kantor BRI yang termasuk kantor wilayah BRI Jakarta 3, dibawah Kantor Cabang Tangerang yang harus mentaati breakdawn RKA (Rencana Kerja Anggaran) kantor pusat BRI tentang pencapaian fee based income melalui internet banking, memiliki total nasabah pinjaman sampai dengan Juni 2012, sejumlah 1.399 debitur dan nasabah simpanan sampai dengan Juni 2012 sejumlah 11.734 orang. Dari 11.734 nasabah simpanan, baru sekitar 118 nasabah yang menggunakan Internet Banking (1\% dari total nasabah simpanan) (laporan bulanan portal DWH BRI:2012). Dari fakta ini, tampak bahwa minat beli atau dalam hal ini minat menggunakan layanan ini oleh nasabah BRI Unit Malabar masih sangat rendah.

Menurut Kinnear dan Taylor (1995: 306), minat beli adalah tahap kecenderungan responden untuk bertindak sebelum keputusan membeli benar-benar dilaksanakan. Segala sesuatu menjadi sama, minat beli secara positif berhubungan terhadap persepsi keseluruhan pada akuisisi dan transaksi nilai (Della Bitta, Monroe dan McGinnis : 1981; Monroe dan Chapman: 1987; Urbany dan Dickson: 1990; Zeithaml: 1988 dalam Grewal, Monroe dan Krishnan, 1998). Zeithaml (1988) mendefinisikan bahwa nilai pelanggan adalah penilaian menyeluruh atas kegunaan suatu produk berdasarkan persepsi atas apa yang diterima dan apa yang dikorbankan (Woodruff, 1997: 141).

Dalam penelitian yang dilakukan oleh Kopalle dan Lehman (1995,p.283) dalam Navarone (2003,p.113) tentang pengaruh pengiklanan terhadap kesuksesan produk, dinyatakan bahwa pengaruh pengiklanan dapat menarik minat beli konsumen, serta menumbuhkan prioritas membeli konsumen dan pembelian ulang konsumen. Sedangkan hasil penelitian Doney dan Cannon (1997, hlm. 44) menunjukkan bahwa keahlian yang dimiliki oleh tenaga penjualan akan berpengaruh positif dengan kepercayaan terhadap tenaga penjualan itu dan pada akhirnya akan mempengaruhi keinginan perusahaan pembeli untuk membeli produk perusahaan penjual.

Selanjutnya, untuk mengakomodasi itu semua dilakukanlah penelitian dengan judul

Pengaruh Iklan, Kemudahan Penggunaan, Resiko dan Citra Perusahaan terhadap Minat Nasabah Internet Banking BRI Pada Nasabah BRI Unit Malabar Tangerang. 


\section{A. Perumusan Masalah}

Berdasarkan latar belakang yang telah diungkapkan di atas, maka rumusan masalah dalam penelitian ini adalah :

1. Seberapa besar pengaruh iklan terhadap minat nasabah Internet Banking BRI?

2. Seberapa besar pengaruh kemudahan penggunaan terhadap minat nasabah Internet Banking BRI?

3. Seberapa besar pengaruh resiko terhadap minat nasabah Internet Banking BRI?

4. Seberapa besar pengaruh citra perusahaan terhadap minat nasabah Internet Banking $\mathrm{BRI}$ ?

B. Kerangka Berpikir

Kerangka berfikir penelitian ini dapat digambarkan sebagai berikut:

PENGARUH IKLAN, KEMUDAHAN PENGGUNAAN, RESIKO DAN

CITRA PERUSAHAAN TERHADAP MINAT NASABAH INTERNET

BANKING BRI PADA BRI UNIT MALABAR TANGERANG

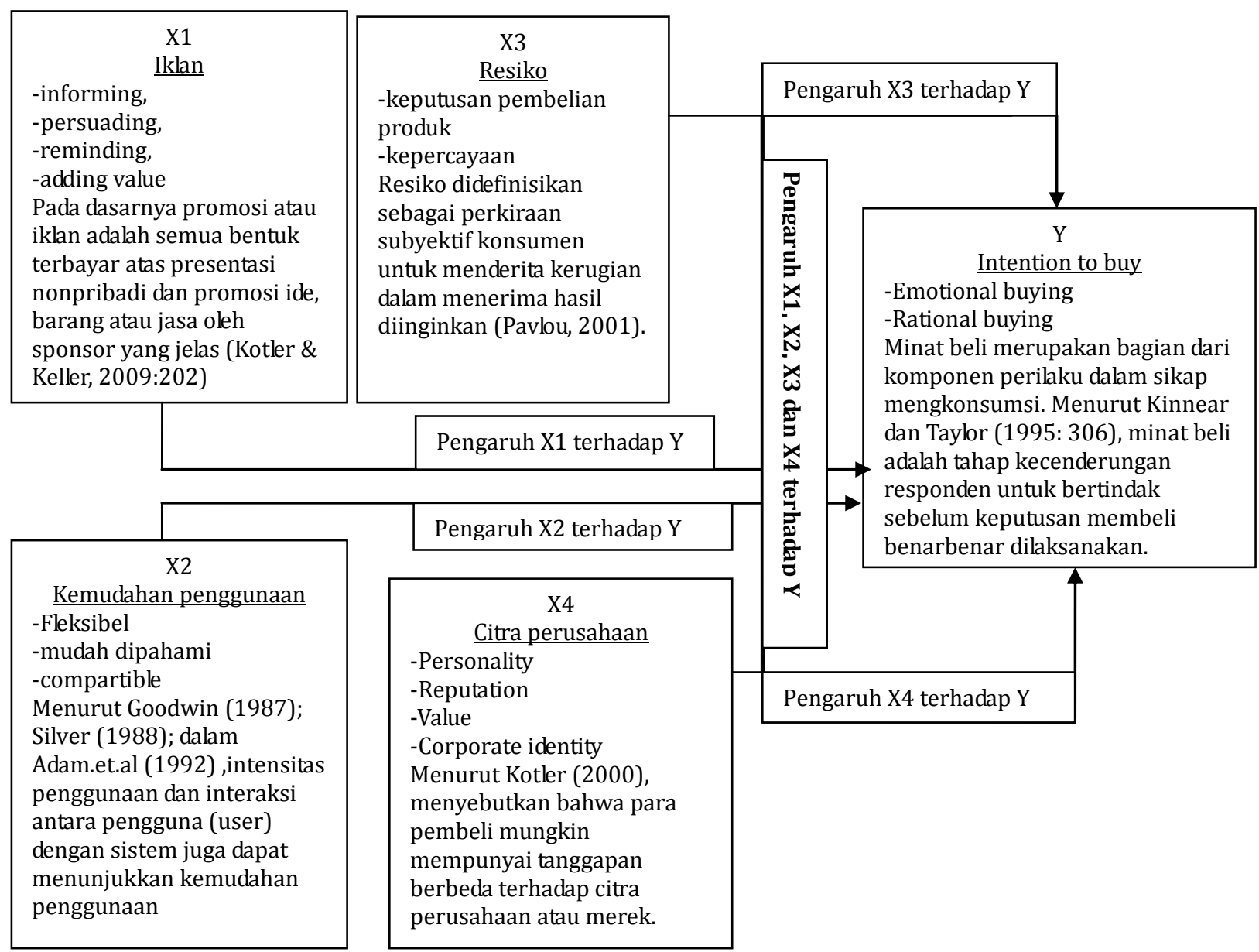

Gambar. 1.1

Kerangka Berpikir 


\section{Landasan Teori}

\section{Iklan}

Pada dasarnya promosi atau iklan adalah semua bentuk terbayar atas presentasi nonpribadi dan promosi ide, barang atau jasa oleh sponsor yang jelas (Kotler \& Keller, 2009:202). Pesan dalam suatu iklan dapat mempengaruhi pengetahuan dan kesan/kesukaan seseorang secara bersamaan. Iklan termasuk kedalam keenam bauran komunikasi pemasaran, yang terdiri dari: iklan, promosi penjualan, acara dan pengalaman, hubungan masyarakat dan publisitas, pemsaran langsung, pemasaran interaktif, pemasaran dari mulut ke mulut dan penjualan personal.

Menurut Kotler Keller (2009) iklan manjangkau pembeli yang tersebar secara geografis. Iklan dapat membangun citra jangka panjang bagi produk atau memicu penjualan cepat. Bentuk iklan tertentu seperti TV memerlukan anggaran besar, sementara bentuk lain seperti surat kabar tidak. Hanya saja kehadiran iklan bias mempengaruhi penjualan. Konsumen mungkin percaya bahwa merek yang diiklankan besar-besaran menawarkan "nilai yang baik". Karena berbagai bentuk dan penggunaan iklan, sulit melakukan generalisasi tentang hal tersebut. Davis, F.D (1989) definisi kemudahan penggunaan (ease of use) sebagai suatu tingkatan dimana seseorang percaya bahwa komputer dapat dengan mudah dipahami. Menurut Goodwin (1987); Silver (1988); dalam Adam.et.al (1992), intensitas penggunaan dan interaksi antara pengguna (user) dengan sistem juga dapat menunjukkan kemudahan penggunaan.

\section{Kemudahan Penggunaan}

Menurut Davis, F.D (1989) definisi kemudahan penggunaan (ease of use) sebagai suatu tingkatan dimana seseorang percaya bahwa komputer dapat dengan mudah dipahami. Menurut Goodwin (1987); Silver (1988); dalam Adam.et.al (1992) ,intensitas penggunaan dan interaksi antara pengguna (user) dengan sistem juga dapat menunjukkan kemudahan penggunaan.

\section{Resiko}

Resiko didefinisikan sebagai perkiraan subyektif konsumen untuk menderita kerugian dalam menerima hasil diinginkan (Pavlou, 2001). Menurut Dowling dan Staelin dalam Pavlou (2001), kalau resiko itu meningkat dari sekedar informasi sampai pada keputusan pembelian produk (transaksi), resiko diasosiasikan dengan kepercayaan (kepercayaan).

Resiko adalah suatu keadaan uncertainty yang dipertimbangkan orang untuk memutuskan atau tidak melakukan transaksi secara online. Orang-orang benar benar mempertimbangkan jarak dan suasana impersonal dalam transaksi online dan infrastruktur global yang banyak mengandung unsur resiko. Dalam penelitian ini indikator resiko dilihat dari tindakan yang dilakukan oleh bank untuk memperkecil resiko dari penggunaan internet banking, diharapkan tindakan yang dilakukan oleh bank untuk memperkecil resiko akan berdampak positif pada minat konsumen untuk menggunakan teknologi yang ditawarkan.

\section{Citra Perusahaan}

Menurut Kotler (2000), menyebutkan bahwa para pembeli mungkin mempunyai tanggapan berbeda terhadap citra perusahaan atau merek. Citra merek adalah persepsi masyarakat terhadap perusahaan atau produknya. Citra dipengaruhi oleh banyak faktor yang di luar kontrol perusahaan. Citra yang efektif akan berpengaruh terhadap tiga hal yaitu : pertama, memantapkan karakter produk dan usulan nilai. Kedua, menyampaikan karakter itu dengan cara yang berbeda sehingga tidak dikacaukan dengan karakter pesaing. Ketiga, memberikan kekuatan emosional yang lebih dari sekadar citra mental. 
Supaya bisa berfungsi citra harus disampaikan melalui setiap sarana komunikasi yang tersedia dan kontak merek.

\section{Minat Beli}

Menurut Kotler dan Keller (2003:181), customer buying decision - all their experience in learning, choosing, using, even disposing of a product. Yang kurang lebih memiliki arti minat beli konsumen adalah sebuah perilaku konsumen dimana konsumen mempunyai keinginan dalam membeli atau memilih suatu produk, berdasarkan pengalaman dalam memilih, menggunakan dan mengkonsumsi atau bahkan menginginkan suatu produk.

Minat beli merupakan bagian dari komponen perilaku dalam sikap mengkonsumsi. Menurut Kinnear dan Taylor (1995: 306), minat beli adalah tahap kecenderungan responden untuk bertindak sebelum keputusan membeli benarbenar dilaksanakan.

Minat beli (willingness to buy) dapat didefinisikan sebagai kemungkinan bila pembeli bermaksud untuk membeli produk (Doods, Monroe dan Grewal, 1991). Segala sesuatu menjadi sama, minat beli secara positif berhubungan terhadap persepsi keseluruhan pada akuisisi dan transaksi nilai (Della Bitta, Monroe dan McGinnis : 1981; Monroe dan Chapman: 1987; Urbany dan Dickson: 1990; Zeithaml: 1988 dalam Grewal, Monroe dan Krishnan, 1998).

Suatu produk dikatakan telah dikonsumsi oleh konsumen apabila produk tersebut telah diputuskan oleh konsumen untuk dibeli. Keputusan untuk membeli dipengaruhi oleh nilai produk yang dievaluasi. Bila manfaat yang dirasakan lebih besar dibanding pengorbanan untuk mendapatkannya, maka dorongan untuk membelinya semakin tinggi. Sebaliknya bila manfaatnya lebih kecil disbanding pengorbanannya maka biasanya pembeli akan menolak untuk membeli dan umumnya beralih mengevaluasi produk lain yang sejenis. Pada kebanyakan orang, perilaku pembelian konsumen seringkali diawali dan dipengaruhi oleh banyaknya rangsangan (stimuli) dari luar dirinya, baik berupa rangsangan pemasaran maupun rangsangan dari lingkungannya.

\section{Metodologi Penelitian}

Jenis penelitian merupakan penelitian kuantitatif karena data penelitian berupa angka-angka yang nantinya akan dianalisis menggunakan statistik Penelitian ini bertujuan untuk mengetahui pengaruh Iklan, kemudahan penggunaan, resiko dan citra perusahaan dan Motivasi Terhadap Minat Nasabah Intenet Banking BRI Unit Malabar Tangerang.

\section{Populasi Dan Sampel}

1. Populasi

Populasi adalah kumpulan dari individu dengan kualitas serta ciri-ciri yang telah ditetapkan (Moh Nazir : 2009). Kualitas atau ciri tersebut dinamakan variable. Sebuah populasi dengan jumlah individu tertentu dinamakan variable.

Berdasarkan pada tempat penelitian yang telah ditetapkan, maka populasi yang dijadikan objek dalam penelitian ini adalah nasabah Internet Banking pada PT. BRI Unit Malabar Tangerang yang berjumlah 54 responden.

2. Sampel

Penarikan sampel dari populasi, Suparmoko menyatakan bahwa '... cukup dengan mengambil presentase tertentu, katakanlah 5\%, 10\%, 15\% dari jumlah populasi (Suparmoko : 1991:42)". Berdasarkan hal ini dapat dipakai sebagai petunjuk unutk menetukan besarnya presentase yaitu:

- Bila populasi $\mathrm{N}$ sedikit sudah memenuhi syarat

- Besarnya sampel hendaknya jangan kurang dari 30 
- Sampel seyogyanya sebesar mungkin selama dana dan waktu masih menjangkau (Suparmoko:1991:42).

Dari populasi nasabah BRI Unit Malabar pengguna internet banking BRI yaitu dari 118 orang tersebut akan ditentukan besaran sampel dengan menggunakan rumus Slovin (Husein Umar, 2008) sebagai berikut.

Dengan besaran populasi nasabah BRI Unit Malabar pengguna internet banking BRI yaitu dari 118 orang, didapat sampel sejumlah 54 orang dengan menggunakan rumus Slovin.

\section{Analisis Data}

Analisis data Analisis data yang digunakan dalam penelitian ini adalah uji validitas dan uji reliabilitas. Pengujian validitas menggunakan rumus korelasi pearson product moment, dengan ketentuan jika hitung $r>$ tabel $r$, berarti instrumen valid. Pengujian reliabilitas dalam penelitian ini menggunakan nilai Alpha Coanbach dengan ketentuan jika Alpha Croanbach ( hitung $r$ ) $>0,60$ berarti instrumen tersebut reliabel. Teknik analisis data antara lain uji asumsi klasik dan analisis regresi ganda. Uji asumsi klasik terdiri dari uji normalitas, uji multikolinearitas dan uji heteroskedastisitas

\section{Uji Normalitas}

Uji normalitas adalah pengujian tentang kenormalan distribusi data. Uji normalitas bisa dilakukan dengan dua cara yaitu dengan "Normal P-P Plot" dan "Tabel Kolmogorov Smirnov" yang paling umum digunakan adalah Normal P- P Plot. Pada normal P- P Plot prinsipnya normalitas dapat dideteksi dengan melihat penyebaran data (titik) pada sumbu diagonal grafik atau dengan melihat histogram dari residualnya. Jika data menyebar di sekitar garis diagonal dan mengikuti arah garis diagonal atau grafik histogramnya menunjukkan pola distribusi normal, maka model regresi memenuhi asumsi normalitas.

\section{Uji Multikolinearitas}

Uji Multikolinearitas dilakukan untuk mengetahui ada tidaknya kemiripan yang dimiliki oleh satu variabel independent dengan variabel independen yang lain dalam satu model. Pengujian multikolinearitas dalam penelitian ini menngunakan VIF (Variance Inflation Factor), dengan ketentuan jika nilai tolerance $>0,1$ dan nilai VIF $<10$, maka data tidak maka data tidak mengalami multikolinearitas.

\section{Uji Heterokedastisitas}

Uji heteroskedastisitas digunakan untuk mengetahui ada atau tidaknya penyimpangan asumsi klasik heteroskedastisitas yaitu adanya ketidaksamaan varian dari residual untuk semua pengamatan pada model regresi. Prasyarat yang harus terpenuhi dalam model regresi adalah tidak adanya gejala heteroskedastisitas. Ada beberapa metode pengujian yang bisa digunakan diantaranya yaitu Uji Park, Uji Glesjer, Melihat pola grafik regresi, dan uji koefisien korelasi Spearman

\section{Analisis Regresi Ganda}

Teknik analisis regresi ganda dipergunakan untuk mengetahui pengaruh Insentif dan Motivasi terhadap Kinerja Karyawan PT. Calibramed. Dengan persamaan regresi $Y=a+$ $\mathrm{b} 1 \mathrm{X}_{1}+\mathrm{b} 2 \mathrm{X}_{2}+\mathrm{b} 3 \mathrm{X}_{3}+\mathrm{b} 4 \mathrm{X}_{4}+\mathrm{e}$

Teknik pengujian hipotesis menggunakan uji parsial dan uji simultan dengan teknik probabilitas, dengan cara membandingkan nilai probabilitas Sig dengan taraf signifikansi 0,05 . Jika nilai probabilitas sig $<0,05$ maka signifikan.

\section{Autokorelasi}

Pengujian Autokorelasi merupakan korelasi atau hubungan yang terjadi antara anggota-anggota dari serangkaian pengamatan yang tersusun dalam serangkaian waktu. 
Salah satu pengujian yang umum digunakan untuk mengetahui adanya auto korelasi adalah uji statistik Durbin Watson, menurut Yohanes Anton Nugroho (2011:102).

Tingkat pengujian autokorelasi adalah seperti table berikut menurut Yohanes Anton Nugroho (2011:104) Secara umum besaran Durbin-Watson ialah sebagai berikut :

Tabel Besaran Durbin-Watson

\begin{tabular}{|l|l|}
\hline \multicolumn{1}{|c|}{ Kesimpulan } & Daerah Pengujian \\
\hline Terdapat autokorelasi positif & $\mathrm{d}<\mathrm{d}_{\mathrm{L}}$ \\
\hline Ragu - ragu & $\mathrm{d}_{\mathrm{L}}<\mathrm{d}<\mathrm{d}_{\mathrm{U}}$ \\
\hline Tidak terdapt autokorelasi & $\mathrm{d}_{\mathrm{U}}<\mathrm{d}<4-\mathrm{d}_{\mathrm{U}}$ \\
\hline Terdapat autokorelasi negatif & $4-\mathrm{d}_{\mathrm{L}}<\mathrm{d}$ \\
\hline
\end{tabular}

\section{Koefisien Determinasi}

Pengujian koefisien determinasi bertujuan untuk mengetahui besarnya pengaruh antar variabel. Nilai koefisien determinasi menunjukkan presentase variasi nilai variabel dependen yang dapat dijelaskan oleh persamaan regresi yang dihasilkan.

\section{Uji Hipotesis}

\section{Uji T}

Untuk melihat apakah pengaruh variabel bebas $\mathrm{X}_{1}, \mathrm{X}_{2}, \mathrm{X}_{3}$ dan $\mathrm{X}_{4}$ signifikan didalam persamaan regresi yang digunakan, maka perlu dilakukan pengujian hipotesis dengan menggunakan uji statistik t. Uji statistik ini adalah dengan membandingkan antara nilai $t$ hitung dengan nilai $t$ tabel dan pada derajat signifikansi 0.05 . Jika $t$ hitung lebih besar daripada t tabel, maka hipotesis nol (Ho) ditolak, sebaliknya jika t hitung lebih kecil dari $t$ tabel maka hipotesis nol (Ho) diterima.

Jika hipotesa nol ditolak artinya kedua variabel bebas yang digunakan dalam penelitian ini secara partial atau secara individual mempunyai hubungan yang signifikan dengan variabel terikatnya. Sedangkan jika hipotesa nol diterima maka kedua variabel bebas yang digunakan dalam penelitian secara parsial tidak mempunyai hubungan yang signifikan dengan variabel terikatnyat digunakan untuk mengetahui hubungan masingmasing variabel independen secara individual terhadap variabel dependen.

\section{Uji F}

Uji statistik $F$ digunakan untuk mengetahui apakah model regresi yang digunakan adalah tepat didalam mempresentasikan data hasil penelitian. Uji statistik $\mathrm{F}$ ini dilakukan dengan membandingkan nilai $F$ hitung dengan nilai $F$ tabel pada $\mathrm{df}=\mathrm{k}, \mathrm{n}-\mathrm{k}-1$, dan pada derajat signifikansi tertentu. Jika $\mathrm{F}$ hitung lebih besar dari pada $\mathrm{F}$ tabel, maka hipotesis nol (Ho) ditolak, sedangkan jika $F$ hitung kurang dari $F$ tabel, maka hipotesis nol (Ho) diterima. Jika hipotesis nol ditolak artinya pada taraf signifikansi tertentu, kedua variabel bebas yang digunakan dalam penelitian secara simultan benar-benar dapat menerangkan variasi dari variabel terikat Y. Sedangkan jika hipotesa nol diterima, maka pada taraf signifikansi tertentu, kedua variabel bebas yang digunakan dalam penelitian secara simultan tidak dapat menerangkan variasi dari variabel terikat $Y$ sebagaimana tercermin dalam model regresi linier. 


\section{E. Hasil Analisis Data dan Hasil Penelitian}

\section{Uji Validitas dan Uji Reliablitas}

Hasil uji validitas dengan menggunakan rumus korelasi product moment dan membandingkan dengan $r$ tabel dengan taraf siginfikansi sebsar $5 \%$ maka diperoleh $r$ tabel yaitu 0,268 sehingga berikut ini hasil intrumen kuesioner no 1 untuk setiap variabel diperoleh nilai:

a. Iklan, instrument kuisioner no 1 diperoleh nilai $r$ hitung $(0,520)>$ tabel $(0,268)$ sehingga instrument no 1 dikatakan valid.

b. Kemudahan pengunaan, instrument kuisioner no 1 diperoleh nilai $r$ hitung $(0,953)$ $>r_{\text {tabel }}(0,268)$ sehingga instrument no 1 dikatakan valid.

c. Resiko, instrument kuisioner no 1 diperoleh nilai $r$ hitung $(0,723)>r_{\text {tabel }}(0,268)$ sehingga instrument no 1 dikatakan valid.

d. Citra perusahaan, instrument kuisioner no 1 diperoleh nilai $r$ hitung $(0,455)>r_{\text {tabel }}$ $(0,268)$ sehingga instrument no 1 dikatakan valid.

e. Minat nasabah, instrument kuisioner no 1 diperoleh nilai $r$ hitung $(0,840)>r_{\text {tabel }}$ $(0,268)$ sehingga instrument no 1 dikatakan valid.

Setelah dilakukan uji validitas dan seluruh intrumen di nyatakan valid, maka tahap selanjutnya adalah uji reliabilitas menggunakan nilai Alpha Croanbach dengan ketentuan jika Alpha Croanbach ( hitung $r$ ) > 0,60 berarti instrumen tersebut reliabel pada setiap variabel kuisioner nya:

a. Iklan, memperoleh nilai alpha croanbach $(0,911)>(0,60)$ sehingga kusioner variabel Iklan dikatakan reliabel.

b. Kemudahan penggunaan, memperoleh nilai alpha croanbach $(0,941)>(0,60)$ sehingga kusioner variabel kemudahan penggunaan dikatakan reliabel

c. Resiko, memperoleh nilai alpha croanbach $(0,902)>(0,60)$ sehingga kusioner variabel resiko dikatakan reliabel

d. Citra perusahaan, memperoleh nilai alpha croanbach $(0,746)>(0,60)$ sehingga kusioner variabel citra perusahaan dikatakan reliabel

e. Minat nasabah, memperoleh nilai alpha croanbach $(0,855)>(0,60)$ sehingga kusioner minat nasabah dikatakan reliabel

\section{Uji Asumsi Klasik}

\section{Uji Normalitas}

Uji normalitas adalah pengujian tentang kenormalan distribusi data. Pada normal P$P$ Plot prinsipnya normalitas dapat dideteksi dengan melihat penyebaran data (titik) pada sumbu diagonal grafik atau dengan melihat histogram dari residualnya. Jika data menyebar di sekitar garis diagonal dan mengikuti arah garis diagonal atau grafik histogramnya menunjukkan pola distribusi normal, maka model regresi memenuhi asumsi normalitas. 


\section{Tabel 1.1 Uji Normalitas}

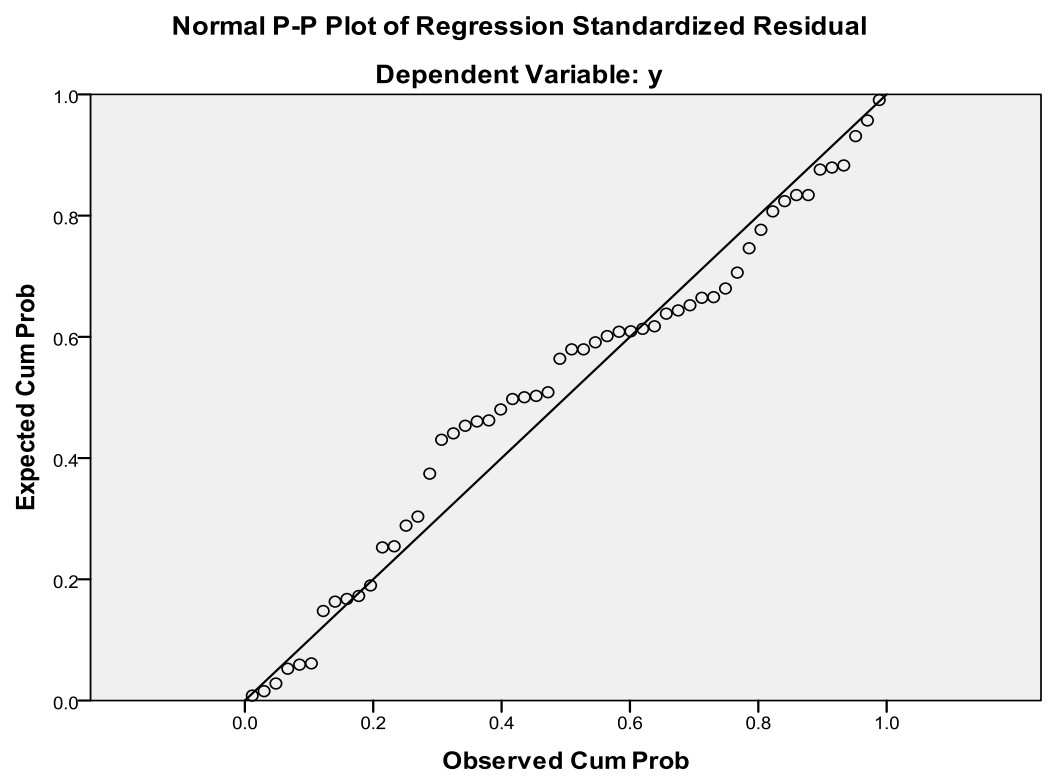

Sumber: Hasil Olah Data Penelitian

Dapat dilihat dari grafik diatas bahwa terlihat bahwa sebaran data berada di sekitar garis diagonal atau tidak terpencar jauh dari garis lurus. Hal ini berarti model regresi ini normal atau mendekati normal sehingga layak dipakai dalam penelitian.

\section{Uji Multikolinearitas}

Pengujian ada tidaknya gejala multikolinieritas dilakukan dengan mempertahankan nilai matriks korelasi yang dihasilkan pada saat pengolahan data serta nilai VIF (Variance Inflation Factor) dan tolerance sebagai berikut:

Tabel. 1.2 Uji Multikolinearitas

Coefficients $^{\mathrm{a}}$

\begin{tabular}{|c|c|c|c|c|c|c|c|c|}
\hline \multirow{2}{*}{\multicolumn{2}{|c|}{ Model }} & \multicolumn{2}{|c|}{ Unstandardized Coefficients } & \multirow{2}{*}{$\begin{array}{c}\text { Standardized } \\
\text { Coefficients } \\
\text { Beta }\end{array}$} & \multirow[b]{2}{*}{$\mathrm{t}$} & \multirow[b]{2}{*}{ Sig. } & \multicolumn{2}{|c|}{ Collinearity Statistics } \\
\hline & & $\mathrm{B}$ & Std. Error & & & & Tolerance & VIF \\
\hline \multirow[t]{5}{*}{1} & (Constant) & 9.698 & 2.028 & & 4.782 & .000 & & \\
\hline & $x 1$ & .034 & .067 & .061 & .506 & .615 & .890 & 1.124 \\
\hline & $x 2$ & -.224 & .102 & -.323 & -2.193 & .033 & .589 & 1.699 \\
\hline & $x 3$ & .262 & .114 & .389 & 2.304 & .025 & .448 & 2.232 \\
\hline & $x 4$ & -.038 & .098 & -.055 & -.390 & .698 & .645 & 1.550 \\
\hline
\end{tabular}

a. Dependent Variable: y (minat nasabah)

Sumber: Hasil Olah Data Penelitian 
Dari hasil output data didapatkan bahwa nilai $\mathrm{VIF}<10,00$ dan nilai tolerance $>0,10$ maka tidak terjadi gejala multikolineritas.

\section{Uji Heteroskedastisitas}

Pengujian heteroskedastisitas dilakukan dengan menggunakan Uji Glejser, yaitu dengan meregresikan variabel residu absolut sebagai variabel dependen dan variabel independen. Jika signifikan berarti ada heteroskedastisitas.

\section{Coefficients $^{\mathrm{a}}$}

\begin{tabular}{|c|c|c|c|c|c|c|c|c|}
\hline \multirow{2}{*}{\multicolumn{2}{|c|}{ Model }} & \multicolumn{2}{|c|}{ Unstandardized Coefficients } & \multirow{2}{*}{$\begin{array}{c}\text { Standardized } \\
\text { Coefficients } \\
\text { Beta }\end{array}$} & \multirow[b]{2}{*}{$\mathrm{t}$} & \multirow[b]{2}{*}{ Sig. } & \multicolumn{2}{|c|}{ Collinearity Statistics } \\
\hline & & $\mathrm{B}$ & Std. Error & & & & Tolerance & VIF \\
\hline \multirow[t]{5}{*}{1} & (Constant) & 9.698 & 2.028 & & 4.782 & .000 & & \\
\hline & $x 1$ & .034 & .067 & .061 & 2.106 & .615 & .890 & 1.124 \\
\hline & $x 2$ & -.224 & .102 & -.323 & -2.193 & .033 & .589 & 1.699 \\
\hline & $x 3$ & .262 & .114 & .389 & 2.304 & .025 & .448 & 2.232 \\
\hline & $x 4$ & -.038 & .098 & -.055 & -.390 & .698 & .645 & 1.550 \\
\hline
\end{tabular}

a. Dependent Variable: y minat nasabah

\section{Gambar. 1.1 Uji Heteroskedastisitas}

Dari hasil pengujian diatas menunjukkan bahwa masing-masing variable mempunyai nilai signifikansi yang lebih besar dari 0,05 $(\alpha=5 \%)$ atau tidak signifikan maka dapat disimpulkan bahwa model regresi yang akan digunakan tidak mengandung gejala heteroskedastisitas. Dengan kata lain hipotesis homoskedastisitas dapat diterima.

\section{Analisis Regresi Linear Berganda}

Tabel 1.3 Analisis Koefisien Korrelasi dan Regresi

\begin{tabular}{|l|r|r|r|r|r|}
\hline \multicolumn{1}{|c|}{ Model } & $\mathrm{R}$ & $\mathrm{R}$ Square & \multicolumn{1}{c|}{$\begin{array}{c}\text { Adjusted R } \\
\text { Square }\end{array}$} & $\begin{array}{c}\text { Std. Error of } \\
\text { the Estimate }\end{array}$ & $\begin{array}{c}\text { Durbin- } \\
\text { Watson }\end{array}$ \\
\hline 1 & $.612^{\mathrm{a}}$ & .375 & .324 & 1.93385 & 1.651 \\
\hline
\end{tabular}

a. Predictors: (Constant), $\mathrm{X}_{4}, \mathrm{X}_{1}, \mathrm{X}_{2}, \mathrm{X}_{3}$

b. Dependent Variable: $Y$

Sumber: Hasil diolah dengan SPSS ver 18

Sumber: Hasil Olah Data Penelitian

Dari hasil olah data SPSS diatas (table 4.9 dan tabel 4.10) diperoleh persamaan regresi sebagai berikut:

$$
\begin{aligned}
\mathrm{Y} & =9.698+0.034 \mathrm{X}_{1}-0.224 \mathrm{X}_{2}+0.262 \mathrm{X}_{3}-0.038 \mathrm{X}_{4} \\
\text { t hitung } & : \mathrm{X}_{1}=2.006 \mathrm{X}_{2}=-2.193 \mathrm{X}_{3}=2.304 \mathrm{X}_{4}=-0.390 \\
\mathrm{R}^{2}= & =.375 \mathrm{DW}=1.651
\end{aligned}
$$

Dari persamaan regresi di atas dapat dilihat bahwa dari semua variabel bebas yang diukur, variabel resiko menggunakan Internet Banking BRI memiliki pengaruh yang 
terbesar terhadap Minat Nasabah bank dalam menggunakan internet banking BRI. Hal ini ditunjukkan oleh nilai koefisien regresi variabel resiko sebesar 0.262 Nilai koefisien regresinya bertanda positif yang berarti semakin rendah resiko menggunakan Internet Banking BRI yang diterima pelanggan, maka akan semakin tinggi pula minat nasabah bank dalam menggunakan internet banking BRI. Variabel iklan memiliki koefisien regresi sebesar 0,034 dengan nilai positif. Artinya semakin bagus iklan Internet Banking BRI ini, maka akan semakin banyak nasabah yang berminat untuk menggunakan Internet Banking BRI. Sedangkan variabel yang paling kecil pengaruhnya terhadap minat nasabah bank dalam menggunakan internet banking BRI adalah variabel kemudahan penggunaan dengan nilai koefesien regresi sebesar - 0,224 yang bernilai negatif. Artinya semakin mudah penggunaan intenet banking, belum tentu mempengaruhi minat nasabah untuk menggunakan Internet Banking BRI. Begitu juga dengan citra perusahaan BRI dengan nilai koefisien sebesar $-0,038$ yang bernilai negatif. Artinya semakin baik citra perusahaan di mata nasabah, belum tentu mempengaruhi minat nasabah untuk menggunakan Internet Banking BRI.

\section{Uji Autokorelasi}

Tabel 1.4 Uji Autokorelasi

\begin{tabular}{|l|l|l|l|l|l|}
\hline \multicolumn{5}{|c|}{ Model Summary $^{\mathbf{b}}$} \\
\hline Model & $\mathrm{R}$ & R Square & Adjusted R Square & Std. Error of the Estimate & Durbin-Watson \\
\hline 1 & $.612^{\mathrm{a}}$ & .375 & .324 & 1.93385 & 1.651 \\
& & & & & \\
\hline
\end{tabular}

a. Predictors: (constant), $X_{1}$ ( iklan), $X_{2}$ (kemudahan penggunaan),

$\mathrm{X}_{3}$ (resiko), $\mathrm{X}_{4}$ (citra perusahaan)

b. Dependent variable: Y (minat nasabah bank dalam menggunakan Internet Banking BRI)

Sumber: Hasil diolah dengan SPSS Ver 18

\section{Sumber: Hasil Olah Data Penelitian}

Berdasarkan Tabel 1.4 terlihat angka D-W sebesar 1.651, dan didapat nilai $d_{L}$ sebesar 1.4069 dan nilai $d_{\cup}$ sebesar 1.7234 (lihat tabel dw pada lampiran), maka berlaku rumus $d_{U}<d<4-d_{U}$, sehingga dapat dinyatakan model regresi linier berganda ini tidak terdapat masalah autokorelasi.; 


\section{Uji Hipotesis}

\section{a. Uji T}

Tabel 1.5 Hasil Uji T

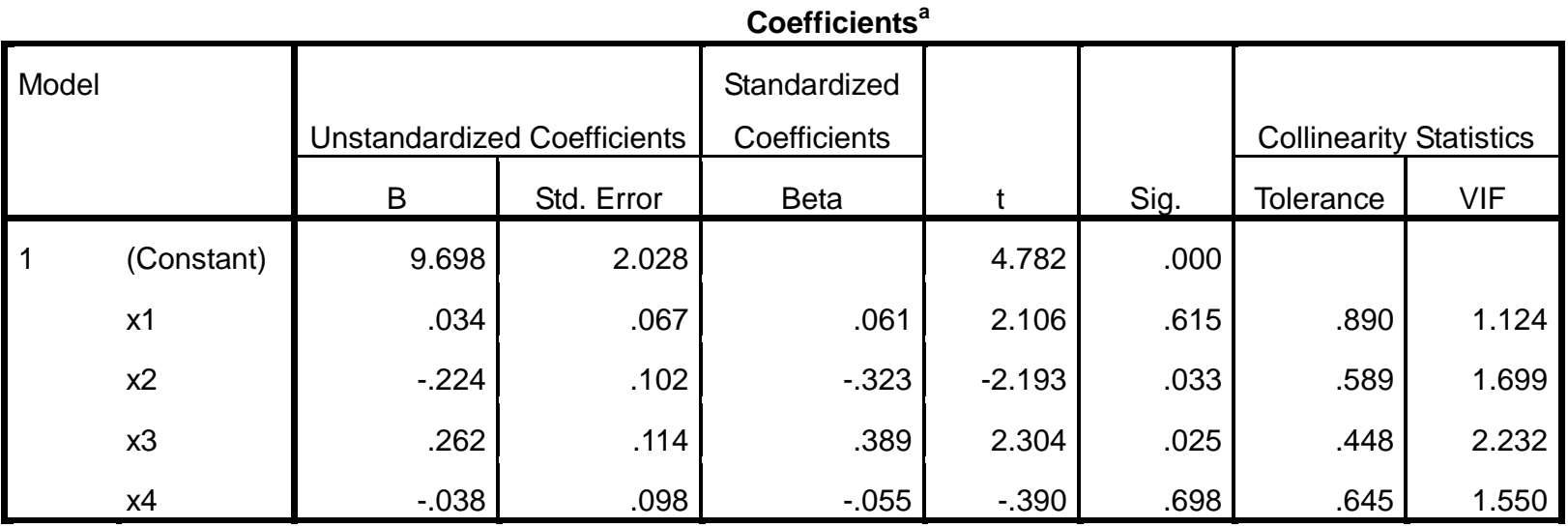

\section{Sumber: Hasil Olah Data Primer}

Untuk menentukan diterima atau ditolaknya hipotesis, maka dilakukan uji t dengan hipotesis sebagai berikut:

1. Hipotesis yang menyatakan bahwa tidak ada pengaruh signifikan variabel iklan terhadap minat nasabah bank BRI dalam menggunakan internet banking BRI, atau dapat ditulis sebagai berikut:

- HO1 : $\beta 1=0$ dan HA1: $\beta 1 \neq 0$

Dari tabeldapat di lihat bahwa t hitung adalah 2.106 dan $t$ tabel adalah 2.00958 (lihat tabel uji t pada lampiran), karena nilai t hitung $>t$ tabel $(2.106>2.00958)$ maka HO1 ditolak atau HA1 diterima, artinya terbukti bahwa ada pengaruh signifikan antara iklan terhadap minat nasabah bank dalam menggunakan internet banking BRI.

2. Hipotesis yang menyatakan bahwa tidak ada pengaruh signifikan variabel kemudahan penggunaan terhadap minat nasabah bank BRI dalam menggunakan internet banking $\mathrm{BRI}$, atau dapat ditulis sebagai berikut:

- HO2: $\beta 2=0$ dan $\mathrm{HA} 2: \beta 2 \neq 0$

Dari tabel dapat dilihat bahwa t hitung adalah -2.193 dan $t$ tabel adalah 2.00958, karena nilai $\mathrm{t}$ hitung $<\mathrm{t}$ tabel $(-2.193<2.00958)$, maka HO2 diterima atau HA2 ditolak, artinya terbukti bahwa tidak ada pengaruh signifikan antara kemudahan penggunaan terhadap minat nasabah bank dalam menggunakan internet banking BRI.

3. Hipotesis yang menyatakan bahwa tidak ada pengaruh signifikan variabel resiko terhadap minat nasabah bank BRI dalam menggunakan internet banking BRI, atau dapat ditulis sebagai berikut:

- HO3: $\beta 3=0$ dan HA3 : $\beta 3 \neq 0$

Dari tabel dapat dilihat bahwa t hitung adalah 2.304 dan t tabel adalah 2.00958, karena nilai $t$ hitung $>\mathrm{t}$ tabel $(2.304>2.00958)$, maka $\mathrm{HO} 3$ ditolak atau HA3 diterima, artinya terbukti bahwa ada pengaruh signifikan antara resiko terhadap minta nasabah bank dalam menggunakan internet banking BRI. 
4. Hipotesis yang menyatakan bahwa tidak ada pengaruh signifikan variabel citra perusahaan terhadap minat nasabah bank BRI dalam menggunakan internet banking BRI, atau dapat ditulis sebagai berikut:

- HO4: $\beta 4=0$ dan HA4 : $\beta 4 \neq 0$

Dari tabeldidapat dilihat bahwa t hitung adalah -0.390 dan $\mathrm{t}$ tabel adalah 2.00958, karena nilai $t$ hitung $<\mathrm{t}$ tabel $(-0.390<2.00958)$, maka HO4 dterima atau HA4 ditolak, artinya terbukti bahwa tidak ada pengaruh signifikan antara citra perusahaan terhadap minat nasabah bank dalam menggunakan internet banking BRI

Secara parsial (uji t) hanya dua variabel bebas (iklan dan resiko) yang secara mempengaruhi variabel dependennya (minat nasabah bank BRI dalam menggunakan internet banking BRI.).

\section{b. Uji F}

Untuk menguji pengaruh Iklan $\left(\mathrm{x}_{1}\right)$, kemudahan penggunaan $\left(\mathrm{x}_{2}\right)$, resiko $\left(\mathrm{x}_{3}\right)$ dan citra perusahaan $\left(x_{4}\right)$ secara bersama-sama terhadap minat nasabah menggunakan internet banking BRI (y), dapat digunakan uji statistik F (uji F), dengan menggunakan taraf signifikansi $5 \%(0,05)$.

Tabel 1.6 Hasil Uji F

\begin{tabular}{|rr|r|r|r|r|r|}
\hline \multicolumn{1}{|c|}{ ANOVA $^{\text {b }}$} \\
\hline 1 & Sum of Squares & df & Mean Square & \multicolumn{1}{c|}{ F } & Sig. \\
\hline & Regression & 110.011 & 4 & 27.503 & 7.354 & $.000^{\mathrm{a}}$ \\
& Residual & 183.248 & 49 & 3.740 & & \\
& Total & 293.259 & 53 & & & \\
\hline
\end{tabular}

a. Predictors: (Constant), x1, x2, x3, x4

b. Dependent Variable: $y$

Sumber: data diolah dengan SPSS Ver 18

\section{Sumber: Hasil Olah Data Primer}

Untuk menentukan diterima atau ditolaknya hipotesis, maka dilakukan uji $\mathrm{F}$ dengan hipotesis sebagai berikut :

- Hipotesis :

$\mathrm{Ho}=$ Menyatakan tidak ada pengaruh signifikan antara pengaruh daya tarik , kemudahan penggunaan, resiko menggunakan Internet Banking, citra perusahaan terhadap minat nasabah bank BRI dalam menggunakan internet banking BRI

$\mathrm{HA}=$ Menyatakan pengaruh signifikan antara pengaruh daya tarik iklan, kemudahan penggunaan, resiko menggunakan Internet Banking, citra perusahaan terhadap minat nasabah bank BRI dalam menggunakan internet banking BRI

Berdasarkan tabel, dari hasil perhitungan didapat nilai $F$ hitung sebesar $7.354 \mathrm{~F}$ tabel adalah 2.56 (karena nilai $F$ hitung $>F$ tabel $(7.354>2.56)$ dan dapat juga dilihat dari nilai signifikannya yaitu sebesar 0.000 dan dibandingkan dengan 0.05 . Karena tingkat signifikan penelitian lebih kecil dari $0.05(0.000<0.05)$ dengan probabilitas signifikansi mendekati nol $(P$ value $=0,000)$, Dengan demikian Ho ditolak, artinya bahwa variabel daya tarik iklan, kemudahan penggunaan, resiko, 
dan citra perusahaan secara bersama-sama mempunyai pengaruh yang berarti terhadap minat nasabah bank BRI dalam menggunakan internet banking BRI

\section{F. Analisis Hasil Penelitian dan Pembahasan}

1. Iklan

a. Dari hasil uji validitas dan reliabilitas maka instrument kuisioner menunjukan valid seperti instirumen kuisioner no $1(0,520>0,268)$ dan begitupun hasil uji reliabilitas kuisioner dimana nilai alpha croanbach $(0,911>0,60)$ dinyatakan reliabel.

b. Dari hasil uji analisis regresi berganda maka diperoleh nilai koefisien 0,034, artinya semakin bagus iklan Internet Banking BRI ini, maka akan semakin banyak nasabah yang berminat untuk menggunakan Internet Banking BRI.

c. Dan hasil uji hipotesis, yaitu uji $\mathrm{t}$ antara Iklan terhadap minat nasabah maka diperoleh nilai $\mathrm{t}_{\text {hitung }} 2,106>\mathrm{t}_{\text {tabel }}$ Sebesar 2,00958 atau berarti $\mathrm{H}_{01}$ ditolak dan $\mathrm{H}_{\mathrm{a} 1}$ diterima, hal ini menunjukan bahwa terdapat pengaruh yang signifikan dari Iklan $\left(\mathrm{x}_{1}\right)$ terhadap minat nasabah $(\mathrm{y})$.

\section{Kemudahan penggunaan}

a. Dari hasil uji validitas dan reliabilitas maka instrument kuisioner menunjukan valid seperti instirumen kuisioner no $1(0,953>0,268)$ dan begitupun hasil uji reliabilitas kuisioner dimana nilai alpha croanbach $(0,941>0,60)$ dinyatakan reliabel.

b. Dari hasil uji analisis regresi berganda maka diperoleh nilai koefisien $-0,224$, artinya semakin mudah penggunaan intenet banking, belum tentu mempengaruhi minat nasabah untuk menggunakan Internet Banking BRI

c. Dan hasil uji hipotesis, yaitu uji t antara kemudahan penggunaan terhadap Minat nasabah diperoleh nilai $t_{\text {hitung }}-2.193>\mathrm{t}_{\text {tabel }}$ sebesar 2,00958 atau berarti $\mathrm{H}_{02}$ diterima dan $\mathrm{H}_{\mathrm{a} 2}$ ditolak, hal ini menunjukan bahwa terdapat pengaruh yang tidak signifikan dari kemudahan penggunan $\left(\mathrm{x}_{2}\right)$ terhadap minat nasabah $(\mathrm{y})$.

\section{Resiko}

a. Dari hasil uji validitas dan reliabilitas maka instrument kuisioner menunjukan valid seperti instrumen kuisioner no $1(0,723>0,268)$ dan begitupun hasil uji reliabilitas kuisioner dimana nilai alpha croanbach $(0,941>0,60)$ dinyatakan reliabel.

b. Dari hasil uji analisis regresi berganda maka diperoleh nilai koefisien 0.262 yang berarti semakin rendah resiko menggunakan Internet Banking BRI yang diterima pelanggan, maka akan semakin tinggi pula minat nasabah bank dalam menggunakan internet banking BRI

c. Dan hasil uji hipotesis, yaitu uji t antara kemudahan penggunaan terhadap Minat nasabah diperoleh nilai $\mathrm{t}_{\text {hitung }} 2.304>\mathrm{t}$ tabel sebesar 2,00958 atau berarti $\mathrm{H}_{03}$ ditolak dan $\mathrm{H}_{\mathrm{a} 3}$ dierima, hal ini menunjukan bahwa terdapat pengaruh yang signifikan dari resiko $\left(\mathrm{x}_{3}\right)$ terhadap minat nasabah $(\mathrm{y})$. 


\section{Citra Perusahaan}

a. Dari hasil uji validitas dan reliabilitas maka instrument kuisioner menunjukan valid seperti instrumen kuisioner no $1(0,455>0,268)$ dan begitupun hasil uji reliabilitas kuisioner dimana nilai alpha croanbach $(0,746>0,60)$ dinyatakan reliabel.

b. Dari hasil uji analisis regresi berganda maka diperoleh nilai koefisien -0.038 yang berarti semakin baik citra perusahaan di mata nasabah, belum tentu mempengaruhi minat nasabah untuk menggunakan Internet Banking BRI.

c. Dan hasil uji hipotesis, yaitu uji t antara citra perusahaan terhadap Minat nasabah diperoleh nilai $t_{\text {hitung }}-.0390>\mathrm{t}_{\text {tabel }}$ sebesar 2,00958 atau berarti $\mathrm{H}_{04}$ diterima dan $\mathrm{H}_{\mathrm{a} 4}$ ditolak, hal ini menunjukan bahwa terdapat pengaruh yang tidak signifikan dari citra peruahaan $\left(\mathrm{x}_{4}\right)$ terhadap minat nasabah $(\mathrm{y})$.

\section{Mlnat Nasabah}

a. Dari hasil uji validitas dan reliabilitas maka instrument kuisioner menunjukan valid seperti instirumen kuisioner no $1(0,840>0,268)$ dan begitupun hasil uji reliabilitas kuisioner dimana nilai alpha cronbach $(0,855$ $>0,60$ ) dinyatakan reliabel.

b. Dari Hasil Korelasi berganda antara Hubungan Iklan, kemudahan penggunaan, resiko dan citra perusahaan terhadap minat nasabah menggunakan internet banking $\mathrm{BRI}\left(\mathrm{X}_{1}, \mathrm{X}_{2}, \mathrm{X}_{3}, \mathrm{X}_{4}\right.$ terhadap $\left.\mathrm{Y}\right)$. maka didapat nilai korelasi ( $r$ ) adalah 0,612. Hal ini menunjukkan bahwa terjadi hubungan yang kuat antara Hubungan Iklan, kemudahan penggunaan, resiko dan citra perusahaan terhadap minat nasabah menggunakan internet banking BRI.

c. Dan hasil uji hipotesis, yaitu uji $F$ maka diperoleh nilai $f_{\text {hitung }}>f_{\text {tabel }}$ yaitu $7,354>2,56$ dan nilai sig $<0,05$ atau 0,000 0,005 " Maka variabel daya tarik iklan, kemudahan penggunaan, resiko, dan citra perusahaan secara bersama-sama mempunyai pengaruh yang berarti terhadap minat nasabah bank BRI dalam menggunakan internet banking BRI

\section{G. Kesimpulan}

Berdasarkan pada hasil penelitian dan pembahasan mengenai berapa besar pengaruh iklan, kemudahan penggunaan, resiko menggunakan Internet Banking, citra perusahaan terhadap minat nasabah bank dalam menggunakan internet banking BRI. Internet Banking BRI, maka berikut ini penulis akan menyimpulkan hasil dari pengamatan yang telah dikemukakan pada bab sebelumnya, sebagai berikut:

1. Ada pengaruh signifikan variabel iklan terhadap minat nasabah bank dalam menggunakan internet banking BRI.

2. Tidak ada pengaruh signifikan variabel kemudahan penggunaan terhadap minat nasabah bank BRI dalam menggunakan internet banking BRI.

3. Ada pengaruh signifikan variabel resiko terhadap minat nasabah bank BRI dalam menggunakan internet banking BRI.

4. Tidak ada pengaruh signifikan variabel citra perusahaan terhadap minat nasabah bank BRI dalam menggunakan internet banking BRI. 


\section{H. Daftar Pustaka}

Arikunto, Suharsimi, (2002), Prosedur Penelitian Suatu Pendekatan Praktek. Jakarta: Rineka Cipta

Downing, Douglas. (1993). Computer and Bussines Tasks, Bussiness Volume, Baron, terjemahan PT Elex Media Komputindo, Jakarta.

Indrianto, Nur dan Supomo, B, (2002), Metodologi Penelitian Bisnis. Edisi Pertama, Cetakan kedua. Yogyakarta: BPFE UGM

Kasmir. Manajemen Perbankan Jakarta, Rajawali Press : 2000.

Kotler, P dan K.L. Keller. (2009). Manajemen Pemasaran Edisi II. Alih Bahasa:

Bob Sabran MM Penerbit Erlangga : Jakarta

Moh Nazir. 2005. Metode Penelitian. Edisi Ketujuh. Jakarta : Ghalia Indonesia

Masyhud, Ali (2006), Manajemen Resiko Strategi Perbankan Dan Dunia Usaha Menghadapi Tantangan Globalisasi Bisnis, PT Raja Grafindo Persada: Jakarta

Nawawi, H, (2005), Perencanaan Sumber Daya Manusia untuk organisasi Profit yang kompetitif. Yogyakarta: Gadjah Mada University Press

Nugroho, Bhuono A. (2005). Strategi Jitu Memilih Metode Statistik Penelitian

dengan SPSS. Andi :Yogyakarta

Sugiyono, (2002), Statistika Unutk Penelitian. Cetakan Keempat. Bandung: CV. Alfabeta

Sugiyono, (2010), Metode penelitian bisnis. Ctakan kedua belas. Bandung: CV. Alfabeta

Sudarmanto, Gunawan (2005). Analisis Regresi Linier Ganda dengan SPSS. Edisi

Pertama. Graha IImu : Yogyakarta

Suparmoko. 1991. Metode Penelitian Praktek. BPFE : Yogyakarta

Suparmoko M. Metode Penelitian Praktis (untuk ilmu-ilmu sosial dan

ekonomi), Edisi 4 BPFE : Yogyakarta 1999

Umar, Husein, (2002), Metode Peneltian Untuk Skripsi dan Tesis Bisnis. Jakarta: PT. Raja Grafindo Persada

Umar, Husein, (2004), Metode Riset IImu Administrasi. PT Gramedia Pustaka Utama: Jakata

Yohanes Anton Nugroho. 2011. It's easy olah data dengan SPSS Edisi Pertama.

Yogyakarta : Skripta Media Creative. 